$$
\begin{aligned}
& \text { كوّارارا زانستيّن مروّاقايهتى يا زانكوّيا زاخوّ } \\
& \text { مجلة العلوم الانسانية لجامعة زاخو }
\end{aligned}
$$

\title{
INVESTIGATING ENGLISH TEACHERS' AWARENESS OF THE TEACHING METHODS THAT SHOULD BE USED IN TEACHING THE SUNRISE SERIES IN ZAKHO CITY, DUHOK-IRAQ
}

\author{
Ivan Hasan Murad
}

Dept. of English Language, Faculty of Humanities, University of Zakho, Duhok, Iraq.

\begin{abstract}
:
This is a small-scale study that aims to investigate Zakho city English teachers' awareness of the teaching methods that should be used in teaching Sunrise Series. The current study collected both qualitative and quantitative data utilising different data collection methods. The participants of the study were 38 teachers from Zakho city teaching in different levels (primary, secondary, and high school). These 38 teachers were chosen to respond to a questionnaire especially designed to achieve the objectives of the study. Nine of these participants were chosen to be interviewed. Each three were chosen to represent a level of education mentioned above. This study also employed different data analysis methods so as to obtain valid results. Results revealed that the majority of the teachers at Zakho city are aware of the English teaching methods but do not know which ones should be used in teaching the Sunrise curriculum. It was also revealed that they are using classical methods in teaching a curriculum which is especially designed to be taught according to the CLT approach. Finally, this study also found that the majority of the teachers need improvement in their teaching practices, particularly in teaching the Sunrise Series.
\end{abstract}

KEYWORDS: Sunrise Series, English Teaching Methods, Zakho city, Communicative Language Teaching, Teaching Levels.

\section{INTRODUCTION}

The current study tries to investigate English teachers' awareness of the teaching methods that should be used to teach the English language curriculum that is taught at primary, secondary and high school levels in Zakho city (the Kurdistan region of Iraq). At the beginning of 2005, the Ministiry of Education in Kurdistan Region-Iraq signed a contract with the British Macmillan company to publish and introduce a new programme for teaching English language in the Kurdistan region of Iraq and this new programme is called "Sunrise series" (Sultan \& Sharif, 2013). Biarayee, (2009) states that the book is designed in an attractive way to attract the student's attention to read and study, i.e. they are colourful and full of different pictures and meaningful materials. Furthermore, Rasheed (2007; cited in Hassan and Ghafor, 2014: 470) states that "the goal of Sunrise curriculum is to provide Kurdish learners with the required level of communication and English language to be able to communicate in English and develop their communicative competence: develop the educational system of this region to cope with the recent developments in foreign language teaching and learning: also teach English from the first basic grade or even from kidnegarten and enable the learners to express themselves adequately with regard to their country's politics, culture, values, and aspirations."

Furthermore, Macmillan (n.d: 42; cited in Sofi-Karim, 2015: 16), claims "Sunrise is based on the communicative approach, integrating listening, speaking, reading, and writing with an explicit focus on grammatical structures." The course develops students' English aptitude through an enjoyable approach to learning by using interesting topic-based units, advanture stories that present a new language, and various activities such as role playing and guided writing tasks. It also contains training packs (a presentation of the teaching methodology and approaches used in the Sunrise course), study skills (methods and useful tips for students to improve their language skills and become independent learners), and how to test Sunrise section, which has a comprehensive set of new tests developed for each level of the
Sunrise course. Moreover, the primary objectives of the Sunrise programme is to teach English as a foreign language at public schools in Kurdistan region and to raise Kurdish students' communicative competence to a level of accuracy and fluency (Sofi-Karim, 2015). In addition, Khidhir (2015) points out that the use of the English language in communicative situations is the main aim of the Sunrise programme.

\section{THE RESEARCH PROBLEM}

It is clear and evident that the Sunrise English curriculum has its teacher's guide as a separate book to guide English language teachers to correctly and effectively use the book. It also tells the teachers about the methods and approaches that should be used in teaching this curriculum. However, since students' English language and communicative skills are not up to the required level by the time they reach university, it is not sure whether or not primary, secondary, and high school English language teachers in Zakho city follow the appropriate teaching methods which should be used in teaching the English "Sunrise" Series. Therefore, this study is conducted.

\section{THE AIM OF THE STUDY}

This study primarily aims to investigate teachers' awareness of the teaching methods that should be used in teaching the Sunrise Series and also to check and see if teachers need improvement in this regard.

\section{THE RESEARCH QUESTIONS}

The current study tries to answer the following research questions: 
a. What do primary, secondary and high school English teachers in Zakho city know about the English teaching methods?

b. What methods do they use in teaching the English Sunrise Series?

c. Which methods should be used in teaching the English Sunrise Series?

d. What prevents them from utilising the already specified teaching methods in teaching the English "Sunrise" Series?

e. Do they need improvement in "the English teaching methods" and in "teaching the Sunrise Series"?

\section{LITERATURE REVIEW}

This section introduces some general methods of teaching English. It also explains how English is taught in the Kurdistan region of Iraq. In addition, it sheds light on some previous studies on English teachers' awareness of the teaching methods that should be used in teaching the Sunrise Series in Zakho city.

\subsection{The Grammar-Translation Method}

The Grammar-Translation Method (henceforth GTM) is one of the methods that are widely used around the world in teaching English as a foreign language (EFL). It was found during the 1960 s and the 1970s that there was need for people to communicate with others during wars and invasions (Harmer, 2007). Stern (1992; cited in Mondal, 2012) argues that a contrastive analysis is undeniably very significant for the second/foreign language learner. Therefore, translation from one form into another can have great effect in language learning. In addition, Alan (1996) points out that the use of translation shapes our way of thinking and to some extent our use of the foreign language. He says that "translation helps us to understand better the influence of the one language on the other, and to correct errors of habit that creep in unnoticed" (cited in Mart, 2013:104). Furthermore, according to Carter \& Nunan (2001) the GTM requiers that students translate the whole texts word by word and memorise numerous grammatical rules and exceptions as well as vocabulary lists. The goal of this method is to enable students to read and translate literary master-pieces and classics.

\subsection{The Direct Method}

According to Qing-xue and Jin-fang (2007) the direct method was a fundamental modification to the GTM through the usage of target language as a means of instruction and communication in the language classroom, and through the avoidance of the usage of the first language and of translation as a technique. It is a move from literary language to the spoken everyday language as the object of early instruction. In this method, the learning of a language was viewed as analogous to the first language acquesition, and the learning processes inolved were often interpreted in terms of an association's psychology. In addition, Rivers (1968; cited in Mart, 2013) states that according to the direct method, students comprehend a language through listening to a countless deal of it and that they learn to speak it by connecting speech with proper action.

\subsection{The Audio-Lingual Method}

Saritha (2016: 726) states that "audiolingualisim holds that in learning a language, speech comes first." Therefore, one should observe the way a native speaker speaks the language and then learn to get a hang of the structural pattern of the second language. Audiolingualism also focuses on language as being the formal, rule-governed system which can be organized to maximize teaching and learning efficiently.

Moerover, Richards and Rodgers (2001) state that this method is centred on developing the speaking skill. That is to say the teacher is the one who directs the class through modeling new structures and making students repeat and imitate them later. Thornbury (1999) suggests that the Audio-lingual method (henceforth ALM) might simply mean the teaching of the grammar syllabus whitout making any reference to grammar in the class.

\subsection{Suggestopedia}

Horn (2005) argues that suggestopedia "is a method of teaching a foreign language by which students learn quickly by being made to feel relaxed, interested and positive" (cited in Rustipa, 2011: 1). Moreover, suggestopedia uses the following four main stages: presentation, active concert, passive concert, and practice (Rustipa, 2011). She further states that suggestopedia instruction has a positive cognitive, motivational, emotional and social effect on the learners. According to Nieves (n.d: 125) "Lozanov's position regarding suggestopedia is that suggestion mainly operates at a subconscious level and it is an important factor in all interchange but it can be tapped to help students achieve their full learning potential."

\subsection{The Silent Way}

Richards and Rodgers (1987: 120) claim that "the silent way represents Gattengo's venture into the field of foreign language teaching." It is based on the premise that the teacher should be silent as much as possible in the classroom and the learners should be encouraged to produce as much language as possible. Elements of the silent way, particularly the use of coloured charts and the coloured cuisenaire rods, grew out of Gettengo's experiances as an educational designer of reading and mathematics programmes.

\subsection{Total Physical Response}

According to Asher (1968), the Total Physical Response (henceforth TPR) Method was designed to accelerate listening comprehension of a foreign language by having subjects give a physical response when they hear a foreign utterance. Furthermore, Widodo (n.d: 237) argues that "this method attempts to centre attention to encouraging learners to listen and respond to the spoken target language commands of their teachers." He also states that TPR is a language teaching method built around the coordination of speech and action; it attempts to teach language through physical (motor) activity.

\subsection{Content Based Instruction}

In the words of Wesche (1993), Content-Based Instruction (henceforth CBI) is aimed at the development of use-oriented second and foreign language skills and is distinguished by the concurrent learning of a specific content and related language use skills. CBI approach views the target language largely as the means through which subject matter content is learned rather than the object of the study (Brinton et al., 1989: 5). Richards and Rodgers (2001: 204) point out that "CBI is an approach to second language teaching in which teaching is organized around the content or information that students will acquire, rather than around a linguistic or other type of syllabus."

\subsection{Community Language Learning}

Nagaraj (2009) argues that Community Language learning (henceforth CLL) tries to eradicate anxiety from learning by changing the relationship between the teacher and student. The Counseling-Learning educational model is applied to language learning, and in this form it became known that CLL seeks to encourage teachers to see their learners as whole persons, whose feelings, intellect, interpersonal relationships, protective reactions, and desire to learn are addressed and balanced. Moreover, Tamura (1983: 17) suggests that "the importance of CLL is the non-evaluative or noncritical attitude on the part of the (so-called) resource person (rather than the teacher)." He further argues that this non-evaluative attitude excludes inhibiting factors in the learning community so that the learner may develop a feeling of security and independence. 


\subsection{Communicative Language Teaching}

Communicative Language Teaching (henceforth CLT) is a language teaching approach that was designed by some British scholars in the early 1970s. This was done when scholars felt the need to have a teaching approach that is purely based on function or communication of language. In 1972, Wilkins, a British linguist, came up with the idea of focusing on communication in teaching the language. Hymes (1975: 11-17) described seven basic functions that language performs for children learning their first language:

a. The instrumental function: using language to get things;

b. The regulatory function: using language to control the behaviour of others;

c. The interactional function: using language to create interaction with others;

d. The personal function: using language to express personal feelings and meanings;

e. The heuristic function: using language to learn and to discover;

f. The imaginative function: using language to create a world of imagination;

g. The representational function: using language to communicate information."

Learning a second/foreign language is similarly viewed by proponents of CLT as acquiring the linguistic means to perform different kinds of functions. At the level of language theory, CLT has a rich, somewhat eclectic theoretical base. Some of the characteristics of this communicative view of language are as follows (Harmer, 2007):

a.Language is a system for the expression of meaning.

b.The primary function of language is for interaction and communication.

c.The structure of language reflects its functional and communicative uses.

d.The primary units of language are not merely its grammatical and structural features, but categories of functional and communicative meaning as exemplified in discourse.

\subsection{Task-Based Language Teaching (TBLT)}

Task-Based Language Teaching (henceforth TBLT) is an example of the communicative approach. In TBLT, language is taught through tasks: these tasks are meaningful and related to possible situations in students' lives outside the classroom. The teacher's role in TBLT is to select a task which has a clear outcome to the students as well as the teacher while the role of the students is to work on the task and finish it. It depends on the nature of the task for which one of the four skills is to be utilised (Richards and Rodgers, 2001). Empirical learning is considered one of the essential theoretical bases in TBLT; students can achieve an intellectual growth when they engage in and reflect on the task that is being used (Harmer, 2007).

According to Nunan (2004: 1), TBLT has strengthened

the following principles and practices:

a. A needs -based approach to content selection.

b. An emphasis on learning to communicate through interaction in the target language.

c. The introduction of authentic texts into the learning situation.

d. The provision of opportunities for learners to focus not only on language but also on the learning process itself.

e. An enhancement of the learner's own personal experiences as important contributing elements to classroom learning.

f. The linking of classroom language learning with language use outside the classroom."
5.11. English Language Teaching in the Kurdistan Region of Iraq

The Kurdistan region of Iraq follows a newly designed programme in teaching English language. Hassan and Ghafor (2014: 79) claim that "English language teaching is paid attention to in the Iraqi Kurdistan region and it is taught as a foreign laguage from the first basic grade till the twelveth preparatory grade in all public schools of this region". They also added that attempts have been made to improve English language teaching and learning in Kurdistan. One of these attempts is the introduction of "Sunrise" programme. Moreover, Biarayee (2009) states that "Kurdistan's Ministry of Education has recently changed the curriculum to include a course book with the title 'Sunrise', which is mainly based on CLT to improve students' communicative abilities" (cited in Abdullah, 2015: 16). However, adopting a more communicative method has little value if Kurdish teachers, who lack training, are to implement CLT using the traditional method of instruction such as Presentation Practice and Production approach (henceforth PPP). Additionally, Vernez, Glulbertson, and Constant (2014; cited in SofiKarim, 2015: 18) argue that the outcome of the English programme has not been satisfactory. Few graduates of the public high schools are able to communicate intelligibly in English. They further state "Students' performance on English national tests is below expectations. For example, results of 2008 grade 9 national tests suggest that about onethird of students did not pass English, receiving grades of lower than 50 percent, which is the passing grade. Fewer than $5 \%$ of the students scored higher than 85 percent in English."

\subsection{Previous Studies}

Hassan and Ghafor (2014) conclude that some of the teaching techniques that are used in the Sunrise Series are not compeletely communicative, but are also a mixture of the GTM, the Audio-Lingual Method, and the Communicative Approach techniques, as refelcted in individual repetition, group repetition, chain drill ...etc. Their study also reveal that one of the big problems in teaching English in the Kurdistan region of Iraq is the lack of well trained and qualified teachers. Hassan and Ghafor (2014:77) further argue that "some of the teachers have not attended any teacher training course to be able to teach this programme while others attended only once or twice. Some of them do not have enough knowledge about this programme and do not know how to teach it and others have problems in selecting and using appropriate teaching techniques." Moreover, Ebadi and Hasan (2016: 21) claim that "in agreement with Sofi-Karim (2015) we may conclude that the English syllabus 'Sunrise' is not taught effectively which is why Kurdish learners fail to meet the required level of the English language." Furthermore, Vernez, (2014) claim that many practitioners in KRI lack the potentials to successfully teach the new curriculum and are used to teaching the traditional curriculum for which they were taught how to teach during their years of preparation (cited in Sofi-Karim, 2015). According to Biarayee (2009), the Sunrise Series is especially designed to be taught in accordance with the communicative approach, integrating listening, speaking, reading, and writing skills. This is to develop students' communicative competence.

\section{METHODOLOGY}

This section is devoted to explain the methodology followed in this study and it falls into four subsections; research sampling, ethical issues, data collection and procedure, and data analysis. 


\subsection{The Research Sample}

Milles \& Huberman (1994; cited in Punch, 2009), argue that it is challenging for any study to represent everyone in the community for whom it is conducted. Therefore, it is wise to take samples taking into consideration the time limit and also the representativeness of the study. The type of sampling chosen for the current study is purposive sampling. Maxwell (1997; cited in Teddlie \& Yu, 2007: 87) defines it as a type of sampling when "particular settings, persons, or events are deliberately selected for the important information they can provide that cannot be gotten as well from other choices." Dawson (2009) states that purposive sampling is effective when only a limited number of people can provide useful data for the study. Thus, the sample of this study consists of 38 male and female primary, secondary, and high school English teachers; 13 male and female teachers were selected from the primary level, 13 from the secondary level and 12 from the high school level. As for the interview sample, 9 teachers were randomly selected to represent the three levels.

\subsection{Ethical Issues}

The current research study is specifically undertaken for educational purposes. However, it is found essential to abide by the ethical rules that any study should go through. According to Dawson (2009: 149) "research ethics is protecting and respecting the people who take part in the study and the honest information these people provide the research with." It is also informing the participants about the topic of the study and the reason why it is conducted. In the current study, participants were clearly informed about the topic of the study and they were also told about the reasons why this study is being conducted in order to gain their consent. They were also informed that their names will be kept anonymous and confidential. Cohen et al (2007) state that it is a must for the researcher to gain the consent of the participant before they actually participate in the study.

\subsection{Data Collection}

The instruements used for data collection in the current study are a questionnaire and semi-structured interviews. Bird (2009: 44) defines questionnaire "as a well-established tool for acquiring information on participants' social characteristics, standard of behaviour or attitudes and their beliefs and reasons for action with respect to topic under investigation." Cohen et al (2007) state that using a questionnaire for the process of data collection is essential as it is very time saving, cheap, and could be used to collect both quantitative and qualitatitive data from a big number of participants in a relatively short time for the research study. It is also a way in which the researcher is sure that all participants answer exactly the same questions in the same way (Hopkins, 2002). However, Kumar (2011) argues that this data collection tool could be risky to utilise because the response rate could be low, and the sample selection process could be biased. Nevertheless, because all participants are educated and appreciate the reason this study is conducted for, they all responded to the questionnaire.

Regarding the second instrument used for data collection purposes, it is semi-structured interviews. Punch, (2009) states that a semi-structured interview is a conversation between two or more people where questions are asked by the interviewer to elicit facts or statements from the interviewee. It does not limit particiapnts to a set of pre-determined responses. Robson (2011) argues that such a type of interview provides an agreed on set of pre-arranged questions in order for the researcher to gain a unified type of answers to the scheduled questions. It is also useful because it helps the researcher to gain valuable information and data from the participants and allows for more detaild questions to be asked (Oppenheim, 2000). This type of interview, on the other hand, could be time consuming: setting up interviews, transcribing, analyzing, and reporting the data could take much time and different interviewers may understand and transcribe interviews' data in different ways (Bell, 1999).
However, if the questions are carefully chosen, the participants are ready to provide clear, valid, and reliable answers which makes interviews be the best instrument for data-collection purposes (Boyce \& Neal, 2006).

As for the procedure of data collection, the questionnaire was especially designed to address the general aim of the current study. The items of the questionnaire were wisely selected in terms of language simplicity and clarity. Before its actual utilisation, the designed questionnaire was given to a jury of university professors consisting of five members specialised in Education and teaching and learning studies to achieve validity. The jury agreed that the items included clearly address the overall aim of the study and the questions are straightforward and easy in terms of the language used. Koshy (2005) and Gilbert (2001) state that the questionnaire designed for a study should be checked for its validity and reliability. Accordingly, the questionnaire was given to three English language teachers twice in two weeks to check its reliability. The teachers were asked to fill it in while thinking out loud. Cohen et al (2007) argue that asking participants to fill in the questionnaire while they think out loud makes the researcher aware of the items they face difficulty responding to. It is worth mentioning that during both sessions (the first and second pilot sessions) no hesitation or uncertainity about the items of the questionnaire was noticed in terms of clarity and content. Therefore, no items were changed, modified, collated, added or deleted.

As for the interview procedure, after the questionnaires were returned, the participants were informed that they might be chosen for a short interview of 20-30 minutes. As the native language of the respondents is Bahdini Kurdish, the interview questions were translated into Kurdish Bahdini along with having a copy in English. This process made it easier for the researcher to convey the real meaning behind the questions asked. Denscombe (2007) states that the researcher should utilise any procedure and method to ensure that the respondents correctly understand the qustions and the items included in the research instruments.

\subsection{Data Analysis Methods}

The data collected via different instruements is analysed using the following three different methods for data analysis: 6.4.1. Microsoft Excel: The Microsoft Excel programme is utilised to analyse the data collected from the questionniare. According to Cohen et al (2007) Mircosoft Excel is an excellent tool for calculation and creating graphical representations. It is a type of a programme that may be used for the basic analysis of data and is also regarded as a very quick and efficient way for the calculation of data collected from a big number of respondents.

6.4.2. Content Analysis and Direct Quotations: Content analysis is defined by Weber (1990; cited in Labelle 2010: 99) as "a research method that uses a set of procedures to make valid interferences from text." The 'content' refers to words, meanings, pictures, symbols, ideas, themes, or any message that can be communicated. The 'text' is anything written, visual, or spoken that serves as a medium for communication (Macnamara, 2005: 2). Along with this analysis method, the 'dirct quotation' technique is also utilised. It is a technique of data analysis where the researcher uses the words of another writer verbatim to support an idea or an argument (Dawson, 2009). It is a sound idea to use this technique when the original statement is well-written and more compelling than a summary or paraphrase. 


\section{RESULTS AND FINDINGS}

The investigation conducted at the sample schools in Zakho city has yielded a number of results and findings (the numbers given to each item and point in the Figures below is out of 38 participants of the study for the questionnaire and out of 9 participants for the interview technique). According to Figure 1 the data gained from the questionnaire reveal that the majority of the teachers are aware of the English teaching methods. About $61 \%$ of the participants have "studied the teaching mehtods", twenty four of the respondents $63 \%$ state that they are "aware of the Presentation, Practice, Production approach" to teach English. The Figure also shows that the majority of the respondents are "aware of the use and application of the classical teaching methods;" twenty one teachers $55 \%$ are aware of this and twelve $31 \%$ are neutral about this point and the rest $14 \%$ state that they are not aware of the use and application of the classical teaching methods.

Regarding the same theme, the data collected from the interviews indicates that the majority of the participants state that they are aware of the classical teaching methods. One of the interviewees stated that "Yes, I am aware of them and I use them in my teaching." Another said "Yes I am aware of them all and I use them all but according to the needs of each topic."

Therefore, generally speaking this Figure shows that the majority of the respondents are aware of the teaching methods of English language.

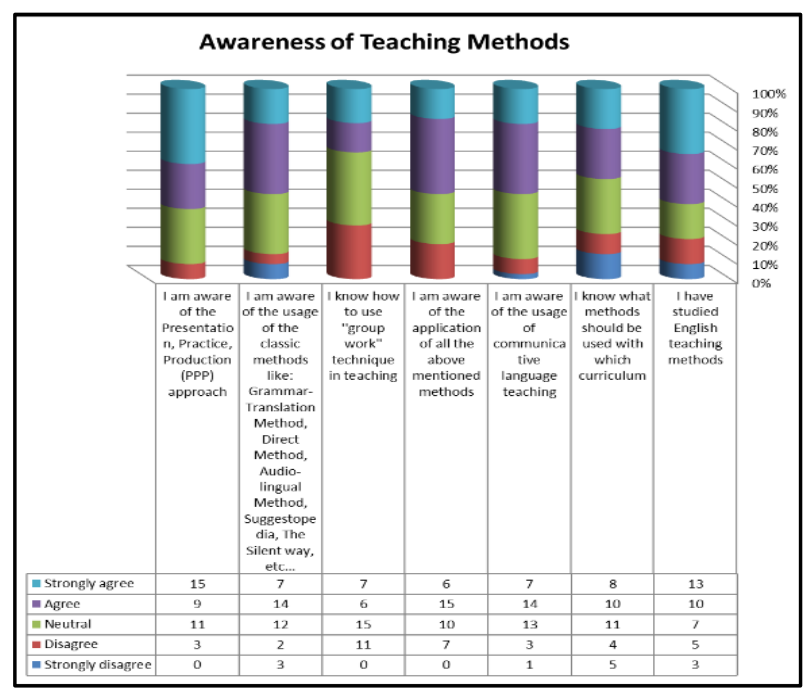

Figure 1. Awareness of Teaching Methods

As for the methods used in teaching, Figure 2 shows the principles of the application of the classical methods have been positively responded to. The Figure shows that twenty two 58\% of the participants state that "when they explain a grammar point, they present the topic and the students practice" and 21 teacher $55 \%$ state that "they always explain and the students do the exercises." The teachers regard this as the application of PPP apporach. However, they only apply the first two 'Ps', which are the "presentation" and "practice" parts and because of the shortage of time they ignore the third ' $p$ ' which is the "production" part.
Figure 2. Application of Classical Teaching Methods

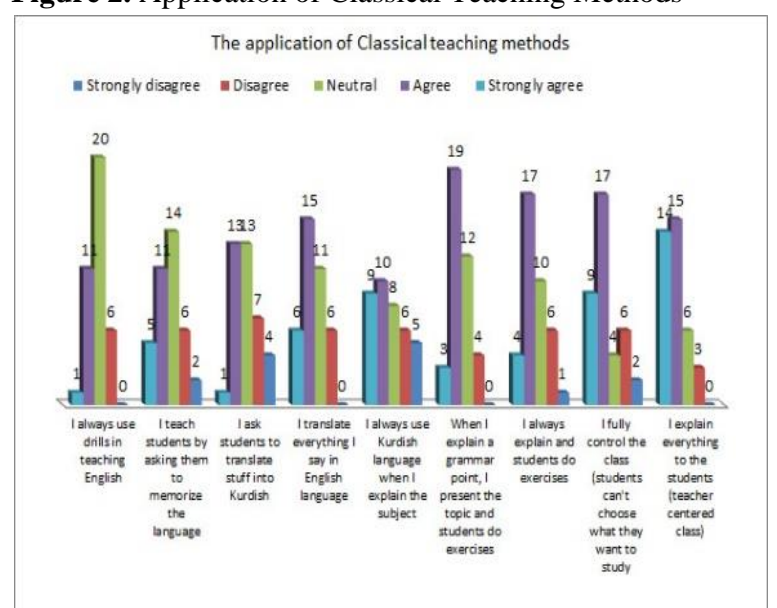

Figure 2 also shows that "using drills", and "asking students to memorize things" have been responded to positively; $32 \%$ of the participants state that they use drills when they teach English as compared to $15 \%$ who state that they do not use the drilling technique. On the other hand, twenty participants $52 \%$ show a neutral response to this point, which indicates the application of audiolingual teaching method. As for "controlling the class" and applying "a teacher-centred" teaching style, Figure 2 shows that the majority of the participants $68 \%$ agree that they follow the former practice and $76 \%$ agree that they apply the latter teaching style. This shows that the majority of the teachers in Zakho city follow the classical teaching methods in teaching English.

Results from the interviews revealed that the majority of the teachers translate from the target language into the students' first language when they explain any topic. When they were asked, do you always translate grammar points from English to Kurdish? Why?" The majority of the teachers stated the following themes:

a.I write everything in English and then I tell them in Kurdish what is this and that."

b."Yes, I always do because students don't understand."

c. "Yes, of course I do. Our students' level is very low and some of them can't even read. I don't know how they passed. But I don't blame our students, I blame... our education system that keeps changing all the time. Our teachers and our students don't know how to deal with this book. They might follow instructions that are given to them by the Ministry of Education. They don't understand that those instructions are methods and techniques used to teach a second language."

Concerning the amount of talking time in the class, almost half of the interviewed teachers state that they give their students opportunities to speak in the class. However, they argue that because the students' level of English is not up to the required level that is why we do not give them many chances to speak and express themselves in the language. The majority of the teachers agree with the one of them who says the following:

"I speak more. I try to make a balance between the time I speak and the students speak, but it doesn't work out because ... time is just not enough to give space to the big number of students to speak especially with their poor English. I need to finish four chapters in two months."

This shows that there are many reasons why teachers do not give their students opportunities to speak in the class. One reason is the poor level of the students' English another reason which is more crucial, is that they have to cover the whole book because it is all included in the final exam.

Figure 3 shows that the practices that reflect the use of communication and tasks in teaching English language have been negatively responded to: only nine teachers $23.6 \%$ state that "they make sure in teaching all the language skills"; 
twelve teachers $31 \%$ state that "they use dialogues in teaching English"; and most importantly only nine participants $23.6 \%$ say that "they make sure that every student speaks and participates in the class". The Figure also shows that teachers heavily use students' first language when they teach them English. Out of the 38 respondents, nineteen $50 \%$ disagree, seventeen $44.7 \%$ strongly disagree, and two $5.2 \%$ show neutral response to the point which says: "I never use Kurdish language in the class." This corresponds with the following point in the Figure which reads: "I always communicate in English with my students" in response to which only fourteen teachers $36.8 \%$ agree they do.

Figure 3 also shows that only twelve teachers $31 \%$ use tasks and exercises in teaching English. The two points "Using studentcentred technique in teaching" and "Using group work and pair work in the class" have also been investigated. Findings from the questionnaire reveal that the former has only seven $18 \%$ positive responses and the latter has only eleven $29 \%$. This purports that English language teachers in Zakho city do not use the interaction teaching technique as a means to help students communicate with each other and wih themselves.

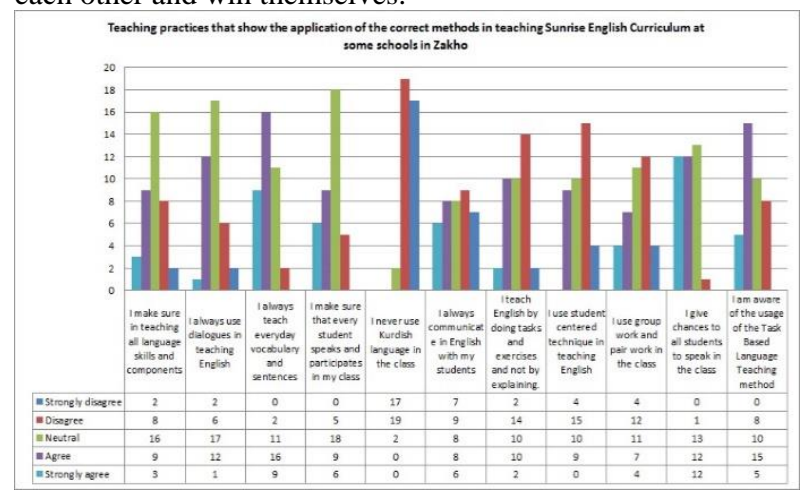

Figure 3. Teaching practices that show the application of the correct methods in teaching Sunrise English Curriculum at some schools in Zakho

However, Figure 3 shows that twenty four teachers $63 \%$ of the respondents agree] that they "give chances to the students to speak in the class." Nevertheless, when this point was asked during the interviews, it was found that the majority of them did not give their students enough opportunities to speak in the class which corresponds with the fourth point from the left hand side of the above Figure.

Regarding the above theme which is about the teaching practices and the application of the appropriate method in teaching the Sunrise Series, it was revealed that the practices the majority of the teachers follow are outdated and reflect the use of some classical methods. When one of the interviewees was asked, "Which method do you use in teaching the Sunrise Series?" he said: "As I earlier stated I am aware of the methods that should be used in teaching the Sunrise Series but I think in our case and in this situation we cannot use those methods. I would use the GTM and the ALM, because teachers can be faster and easily finish the chapters before the end of each course." Another interviewee said: "I don't know because I did not study methods of teaching but I think we should follow the guide that is given to us by our supervisor". A third one said: "I don't know about any methods so how can I tell you which one should be used. All I do is I explain the subject and the students do the exercises. We don't do many exercises because we don't have time I explain and I do the exercises with the students to finish the subject."

The above quotations along with the data collected from the nine interviewees show that few teachers have an idea about which methods should be used in teaching the Sunrise Series but they do not follow them since they may be unaware of the actual application of them.

As for the methods and approaches that should be used in teaching the Sunrise Series, Figure 4 shows the participants' responses to the question of "Which of the following methods do you think should be used to teach the Sunrise Series?"

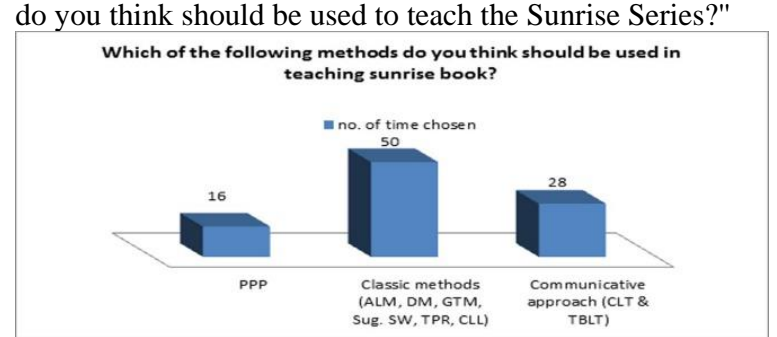

Figure 4. The methods that teachers think should be used in teaching Sunrise Series

The participants were asked to choose three methods they think should be used in teaching the Sunrise Series to check whether or not they are aware of the method that should be used in teaching the Sunrise Series. The results in Figure 4 show that the classical methods were chosen 50 times, which is the highest number of times chosen among all methods. The Communicative Approach comes in the second place for being selected 28 times. As compared with the literature on the method that should be used in teaching the Sunrise Series, it becomes apparent that the majority of the teachers are unaware of the exact teaching method that should be used in teaching the Sunrise Series. This is because according to some scholars, the Sunrise Series should be taught using the Communicative Approach in the first place and with specific topics like grammar points PPP and some classical methods should be used.

When the interviewees were asked which method they think should be used in teaching the Sunrise Series, surprisingly none of the respondents gave the correct answer to this question. The majority of them chose the GTM and the ALM and the rest chose CLL, CBI, except one who chose PPP. Below are some sample respones:

a. "I don't know because I did not study methods of teaching but I think we should follow the guide that is given to us by our supervisor."

b. "I don't know any methods so how can I tell you which one should be used."

c. "I don't know anything of these methods so I don't know which one to choose."

The above responses clearly suggest that the majority of the teachers are oblivious about which method should be utilised in teaching the Sunrise Series. Teachers may have been limited to use some specific teaching methods due to certain issues. This part will bring forth the obstacles that might prevent teachers from applying the appropriate method in teaching the Sunrise Series.

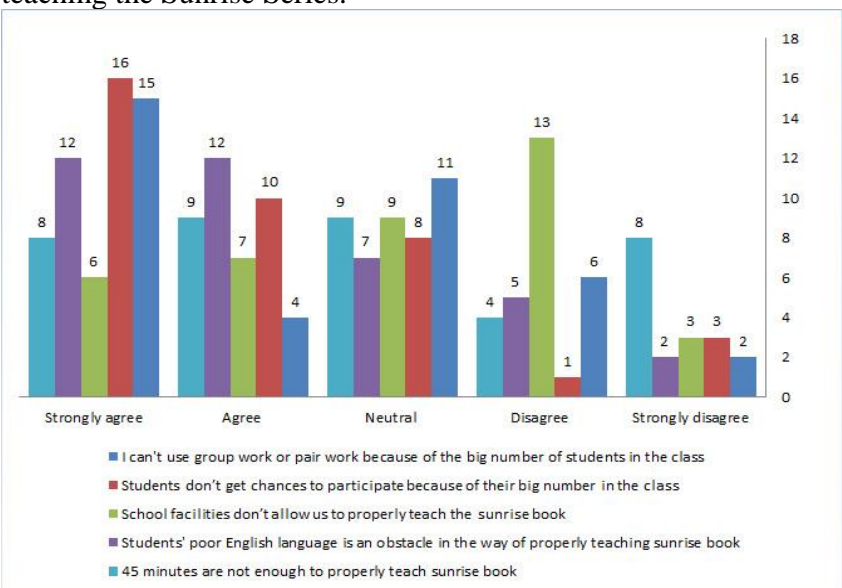

Figure 5. Obstacles hindering the application of CLT \& TBLT in teaching the Sunrise Series 
It is apparent from Figure 5 that teachers are not be able to apply "group work" and "pair work" teaching techniques because of the "big number of students in the class". Thus $50 \%$ of the respondents agree that big number of students in each class is the reason why they cannot apply group-work and pair-work techniques inside the classroom. The Figure also shows that the majority of the teachers $68 \%$ agree that because of the " big number of students in the class" the teachers cannot give sufficient opportunities to every student to participate in the class. As for whether or not "school facilities do not allow teachers to properly teach the Sunrise Series, $42 \%$ of the participants disagree with this point, $24 \%$ are neutral, and $34 \%$ agree that school facilities do not allow them to properly teach the Sunrise Series. Regarding students' poor level of English, the majority of the participants $63 \%$ agree that "the students' poor English is an obstacle in the way of properly teaching the Sunrise Series", $18 \%$ disagree and the rest are neutral about this point. The Figure also shows that $45 \%$ of the participants agree that " 45 minutes are not enough to properly teach the Sunrise Series," 32\% disagree and $23 \%$ neither agree nor disagree.

The majority of the respondents said that because of the "shortage of time", "students' low level", "availability of big number of students in the class", and the fact that "all the curriculum should be covered" that they are unable to utilise CLT, TBLT, and PPP together in teaching Sunrise book.

To get the subjects' answers to the last research question, two points were given to the participants. The first points checks if the teachers "need to attend an ELT methodology course" and the other investigates whehter they "need to be taught how to teach the Sunrise Series." Results from Figure 6 below show that about $50 \%$ of the respondents agree that "they need to be taught how to teach the Sunrise Series," about $28 \%$ of them state that "they do not need to be taught how to teach the Sunrise Series," and 23\% are neutral about this point. As for whether or not "they need to attent an ELT methodology course," $45 \%$ of the teachers agree and $21 \%$ disagree. The rest of the respondents are neutral about this point.

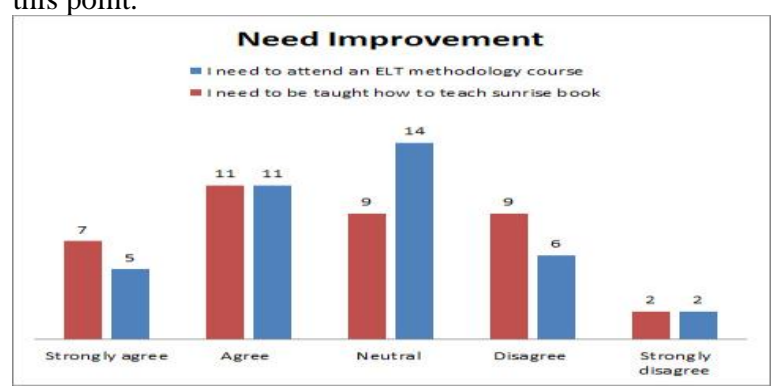

Figure 6. Need Improvement

The data from the interviews disagreed with the data gained from the questionnaire, which reveals that the majority of the teachers are in need of an ELT course to know more about the methods of teaching English language, especially the ones that should be used in teaching the Sunrise Series. Interviews also reveal that all teachers need to be taught how to teach the Sunrise Series, how to overcome issues like large-sized classes, how to effectively and efficiently cover the whole curriculum, and how to help students learn.

\section{DISCUSSION}

The results of the present study show that the majority of the English teachers in Zakho are aware of the methods that are used in teaching English. Harmer (2011) states that it is essential for teachers to know about the methods that should be used in teaching any field of study. This is because the method is what helps the teacher to correctly deal with a particular curriculum. No Studies on the awareness of the methods of teaching English were conducted before the present study in Duhok governorate, especially in Zakho city. However, one could argue that awareness of the method to be used is not enough unless it is correctly used and applied (Scrivener 2011). Therefore, the actual practices of the English teachers in Zakho city show that they mostly use classical methods (the GTM, the ALM, and the Direct Method) in teaching the Sunrise curriculum. Murad (2012: 12) states that "English language teaching in Kurdistan has witnessed a number of changes in both curriculum and methods of teaching as a result of the changes made on the policy of its system." Teaching in Kurdistan used to be based on the teaching of the curriculums provided by the Ministry of Education in Baghdad. Al-Joubori (2006) states that the English curriculum the Ministry of Education in Baghdad used to provide was all based on the GTM and the ALM. Kurdish English teachers were widely using these classical methods and were also well trained to apply them (Mathaba, 2005). Domily (2010) states that it seems that these methods (GTM \& ALM) have an undue effect on the teaching style of most of the Iraqi practitioners as they are still following them. Therefore, this could be the reason why English teachers in Zakho are following the wrong methods in teaching the Sunrise curriculum. Though they are aware of the methods of teaching English, the majority do not know which method should be used in teaching the Sunrise curriculum. As it is stated in the literature review, it is impractical to introduce a curriculum without training courses provided for teachers who will teach the curriculum (Vernez, Glulbertson, and Constant, 2014).

However, the reason for not applying the correct method in teaching the Sunrise Series is not attributed to the teachers only, but also to some other factors that are nationally and internationally seen as challenges. "Having a big number of students in the class," "the shortage of time," and "the students' low level of English" are also the reasons why teachers are not applying the correct methods in teaching the Sunrise Series. Yet, Harmer (2011) states that having a big number of students could be beneficial if teachers know how to deal with it. Hess (2001) states that there are many ways through which sudents can work well in groups. This could solve the problem of having a big number of students in the class and also students can make use of each other's experiences in learning and improving their English. Hess (2001) and Harmer (2007) state that teachers can deal with low-level students by providing them with materials that suit their level, even if the students have little command of English, they would be able to practice and communicate well with each other in the target language.

The above argument is in line with the results reached regarding the last research question in this study, which is "Do English language teachers in Zakho city need improvement in "the English teaching methods" and in "teaching the Sunrise Series?" Due to their unawareness of the ways of dealing with certain teaching stiuations, the teachers need to be taught how to teach this curriculum and also need to attend an ELT training course.

\section{CONCLUSIONS AND ECOMMENDATIONS}

In view of the above results and findings, it is concluded that primary, secondary, and high school English teachers in Zakho city are aware of the English teaching methods but they do not know which method should be used in teaching the Sunrise curriculum. It is also concluded that the majority of English teachers in Zakho city use classical teaching methods in teaching the Sunrise curriculum whereas it has been found that the CLT, TBLT, and sometimes PPP methods and approaches should be used to successfully teach the Sunrise curriculum.

This study also concludes that the reasons why English teacher use classical methods in teaching the Sunrise Series are: the fact that they have been trained to use them as they 
have long been using them, the "large number of students in the class," the "shortage of time," and the "students' low level of English." Finally, this study reveals that the majority of English teachers in Zakho city need to be taught how to teach the Sunrise Series. They also need to attend an ELT course to become aware of the English teaching methods: their principles, application, and use.

Based on the above conclusions, the following recommendations are put forward, as follows:

1. The local Directorate of Education in Duhok-Zakho city needs to provide English teachers with short teaching methodology courses on a regular basis to raise their awareness of teaching methods and provide them with the most updated teaching practices in the field of English language teaching and learning.

2. The local Directorate of Education also needs to provide the English teachers in Zakho city with a special course on "how to teach the Sunrise Series" to help them know more about it and how it should be taught.

3. English teachers in Zakho city should also be trained and adviced to follow up the most updated teaching practices to be able to deal with different challenges.

4. The local Directorate of Education should make sure that each English class includes not more than 25 students to help involve all students and give everyone a chance to speak and practice English as school may be the only place where students can practice speaking English.

\section{REFERENCES}

Abdulla, A. M. B. (2015). Kurdish Students Perseption Towards Communicative Language teaching at a University in Kurdistan Regin Iraq. European Scientific Journal, Vol. 1. Special Edition

Al-Joubori, N. (2006). 'Shifting Sands of English Language Teaching in Iraq Language Policy and Planning'. Journal of the College of Education for Women, Vol 17. No (2), 579-592.

Aqel, M. Ishraq. (2013). The Effects of Using Grammar-Translation Method on Acquiring English as a Forign Language. International Journal of Asian Science, Vol. 3, No. 12.

Asher, J. J. (1968). The Total Physical Response Method for Second Language Learning, Produced by the clearinghouse.

Bell, J. (1999). Doing your Research Project ( $3^{\text {rd }}$ ed.). Milton Keynes: Open University Press.

Biarayee, O. F. G. (2009). Assessing the Suitability of "Sunrise" Programme to the Kurdish Learners of the Seventh Basic Grade in the Schools of Erbil City. Unpublished Master Dissertation. University of Salahaddin.

Bird K. D. (2009) The use of questionnaires for acquiring information on public perception of natural hazards and risk mitigation-a review of current knowledge and practice. Nat. Hazards Earth Syst. SCI., Vol 9, 1307-1325

Boyce, C. \& Neal, P. (2006). Conducting in- depth Interviews: A Guide For Designing and Conducting In - Depth Interviews, pathfinder International Tool Series.

Brinton, D., Snow, M. A., \& Wesche, M. B. (1989). Content-based second language instruction. Boston: Heinle \& Heinle Publishers.

Carter, R. \& Nunan, D. (ed.) (2001). The Cambridge Guide to Teaching English to Speakers of Other Languages. Cambridge: Cambridge University Press.

Cohen, L., Manion, L. \& Morrison, K. (2007). Research Methods in Education. $\left(6^{\text {th }}\right.$ ed).Routledge: London.

Dawson, C. (2009). Introduction to Research Methods: A Practical Guide for Anyone Undertaking a Research Project. ( $4^{\text {th }}$ ed.). Oxford: How To Books Ltd.

Denscombe, M. (2007) The Good Research Guide.Maidenhead: OUP.

Domily, K. (2010). Exasperated and Confused Students'. PayamaZankoy. 52 (9) [online] available at University of Duhok http://uod.ac/articles_files/Peyam_09.pdf

Ebadi, S. \& Hasan, M. I. (2016). A Critical Analysis Tasks EFL Textbook: A Case Study of Sunrise 1. English for Specific Purposes World, V. 17, Issue. 49.
Gilbert, N. (ed.) (2001). Researching Social Life (2 ${ }^{\text {nd }}$ ed.). London: SAGE Publications Ltd.

Harmer, J. (2007) The Practice of English Language Teaching ( $4^{\text {th }}$ ed.). Edinburgh: Pearson Education Limited.

Harmer, J. (2011) The Practice of English Language Teaching ( $5^{\text {th }}$ ed.). Edinburgh: Pearson Education Limited.

Hassan, .R. F \& Ghafor, F. O. (2014). Assessing The Suitability of "Sunrise" programm to the Kurdish Learner of the Seventh Basic Grade in the School of Erbil City. Journal of Teaching and Education. Vol 03, No.(03): pp. 469-482

Hess, N. (2001). Teaching Large Multiplevel Classes. United Kingdom: Cambride University Press.

Hopkins, D. (2002). A Teacher's Guide to Classroom Research. (3 ${ }^{\text {rd }}$ ed). England: Open Universiy Press.

University Press.Hymes, D. H. (1975). Breakthrough into performance. In D. Ben-Amos \& K. Goldstein (Eds.), Folklore: Performance and communication (pp. 11-74). The Hague: Mouton.

Khidhir, A. M. (2015). The Assessment and Suitability of "Treasure Island" as literary reader in Grade Twelve in Kurdistan's Schools, $16^{\text {th }}$ Internatiopnal Visible Conference on Eduecational Studies and Applied Linguistics. (P. 319$332)$.

Koshy, V. (2005) Action Research for Improving Practice: A Practical Guide. London: Paul Chapman Publishing.

Kumar R. (2011). Research methodology: A Step-by-Step Guide for Beginners ( $3^{\text {rd }}$ edition). SAGE Publications LTD.

Labelle J. ( 2010). Selecting ELL Textbooks: a Content Analysis of L2 Learning Strategies. A journal of language teaching and research. Academy Publisher, vol. 1, no. 4.

Macnmara J. (2005). Media Content Analysis: its uses; benefits and best practice methodology. Asia pacific public relation journal, Vol. 6, No. 1, pp 1-34.

Mart, T. C. (2013). The Grammar-Translation Method and the use of Translation to Facilitate Learning in ESL Classes, Journal of Advantages in English Language Teaching. Vol. 1, No. 4.pp: 103-105

Mathaba (2005). 'English Language Teaching in Kurdistan'. Available <http://www.ekurd.net/mismas/articles/misc2005/1/lang uageteaching.htm>

Mondal, K. N. (2012). A Comparative Study of Grammar Translation Method and Communicative Approach in Teaching English Language. New York Science Journal, Vol. 5, No. 5.pp: 86-93

Murad, H. I. (2012). Evaluating the effectiveness of speaking teaching materials that are used in a particular language organization in Kurdistan region/Iraq. Unpublished Master Dissertation. University of Huddersfield.

Nagaraj, P. (2009). Application of Community Language Learning For Effeective Teaching. The modern journal of applied linguistics, Vol. 1, No. 3.pp:75-81

Nieves, V. N. (n/d). Effects of the Suggestopedia Method on Attitudes and Language Achievement in English Among Ninth Grade Puerto Rican Students. Education, pp: 125177. Available at: http://cai.sg.inter.edu/reveduc\$/prdocs/V58A12.pdf

Nunan, D. (2004) Task-Based Language Teaching. Cambridge: Cambridge University Press.

Oppenheim, A. N. (1992) Questionnaire Design, Interviewing and Attitude Design. London: Continuum.

Punch, K. F. (2009) Introduction to Research Methods in Education. London: SAGE.

Qing-xue, L. \& Jin-fang, S. (2007). An Analysis of Language Teaching approaches and Methods-Effectiveness and Weakness. US China Education Review, V. 4, N. 1.pp: 69-71

Richards, J. C. \& Rodgers, T. S. (2001) Approaches and Methods in Language Teaching ( $2^{\text {nd }}$ ed). Cambridge: Cambridge University Press.

Robson, C. (2011). Real World Research: A Resource for Users of Social Research Methods in Applied Settings. ( $3^{\text {rd }}$ ed). Oxford: Wiley Publication Ltd.

Rustipa, K. (2011). Suggestopedia: How does it Accelerate Language Learning. LITE, V. 7, N. 1.pp: 1-7

Saritha, R. V. K. (2016). Audio-Lingual in ELT. Scholars Journal of Arts, Humanities and Social Science, V. 4, N. 6B 
Scrivener, J. (2011). Learning Teaching: The Essential Guide to English Language Teaching. ( ${ }^{\text {rd }}$ ed.). Oxford: Macmillan Publishers.

Sofi-Karim, M. (2015). English Language Teaching in the Kurdistan Regin of Iraq, Unpublished Master's Thesis. httpl|WWW.researchgate. net|publication|280131563. Copyright by Mahdi Sofi-Karim.

Sultan, I. A \& Sharif, A. H. (2013). The Efficiency of Teaching Listening Comprehension of " Sunrise Series" in Erbil Governrate. Majalat Adab AL-Farahidy, V. 1, N. 16. pp:2-43

Tamura, T. E. (1983). Concept on the Methodology of Teaching English. The Economic Journal of Takasaki City University of Economic. V. 48, N. 3.pp:169-188

Teddlie C. and Yu F. (2007) Mixed Methods Sampling: A Typology with Examples. Louisiana State University, Baton Rouge. Vol (1) no. 1: pp:77-100
Thornbury S. (1999) How to teach Grammar. Edindurgh, Pearson Education Limited

Wesche, M. B. (1993). Discipline-based approaches to language study. Research Issues and Outcomes. In M. Kurger \& F. Ryan (Eds). Language and Content : Discipline and content based approaches to Languages study. Lexington, MA. DC. Health.

Widodo, P. H. (2005). Teaching Childern Using Total Physical Respose (TPR) Method: Rethinking. Bahasa Dan Seni, V. 33, N. 2.

\section{Appendices}

\section{1: Questionnaire}

Dear sir/madam,

Thank you very much for showing interest in participating in our small scale study. This study is to investigate English teachers' awareness of the ELT methodologies and the ones that should be used in teaching English sunrise book in Zakho city. Please carefully read the following items and tick the appropriate option that you think best goes with your practice.

\begin{tabular}{|ll|l|}
\hline$\bullet$ & Please tick your teaching level: & Please Tick $\checkmark$ \\
\hline 1. & Primary school teacher & \\
\hline 2. & Secondary school teacher & $\checkmark$ \\
\hline 3. & High school teacher & \\
\hline
\end{tabular}

\begin{tabular}{|c|c|c|c|c|c|c|}
\hline No. & Item & $\begin{array}{l}\text { Strongly } \\
\text { disagree }\end{array}$ & Disagree & Neutral & Agree & $\begin{array}{l}\text { Strongly } \\
\text { agree }\end{array}$ \\
\hline 1 & I have studied English teaching methods & & & & & $\checkmark$ \\
\hline 2 & I know what method should be used with which curriculum & & & & $\checkmark$ & \\
\hline 3 & I am aware of the usage of communicative language teaching & & & $\checkmark$ & & \\
\hline 4 & I am aware of the usage of the Task Based Language Teaching method & & & $\checkmark$ & & \\
\hline 5 & $\begin{array}{l}\text { I am aware of the usage of the classic methods like: Grammar- } \\
\text { Translation Method, Direct Method, Audio-lingual Method, } \\
\text { Suggestopedia, The Silent way, etc... }\end{array}$ & & & & & $\checkmark$ \\
\hline 6 & I am aware of the Presentation, Practice, Production (PPP) approach & & & & & $\checkmark$ \\
\hline 7 & I am aware of the application of all the above mentioned methods & & & & $\checkmark$ & \\
\hline 8 & I explain everything to the students (teacher centered class) & & & & & $\checkmark$ \\
\hline 9 & I fully control the class (students can't choose what they want to study & $\checkmark$ & & & & \\
\hline 10 & I give chances to all students to speak in the class & & & & & $\checkmark$ \\
\hline 11 & I use group work and pair work in the class & & & & $\checkmark$ & \\
\hline 12 & I always explain and students do exercises & & $\checkmark$ & & & \\
\hline 13 & I use student centered technique in teaching English & & & $\checkmark$ & & \\
\hline 14 & $\begin{array}{l}\text { When I explain a grammar point, I present the topic and students do } \\
\text { exercises }\end{array}$ & & $\checkmark$ & & & \\
\hline 15 & I teach English by doing tasks and exercises and not by explaining. & & $\checkmark$ & & & \\
\hline 16 & I always communicate in English with my students & & $\checkmark$ & & & \\
\hline 17 & I never use Kurdish language in the class & & $\checkmark$ & & & \\
\hline 18 & I always use Kurdish language when I explain the subject & $\checkmark$ & & & & \\
\hline 19 & I make sure that every student speaks and participates in my class & & & $\checkmark$ & & \\
\hline 20 & I translate everything I say in English language & & $\checkmark$ & & & \\
\hline 21 & I ask students to translate stuff into Kurdish & & & & $\checkmark$ & \\
\hline 22 & $\begin{array}{l}\text { I can't use group work or pair work because of the big number of } \\
\text { students in the class }\end{array}$ & & & & $\checkmark$ & \\
\hline 23 & $\begin{array}{l}\text { Students don't get chances to participate because of their big number } \\
\text { in the class }\end{array}$ & $\checkmark$ & & & & \\
\hline 24 & I know how to use "group work" technique in teaching & & $\checkmark$ & & & \\
\hline 25 & I always teach everyday vocabulary and sentences & & & $\checkmark$ & & \\
\hline 26 & I always use dialogues in teaching English & & $\checkmark$ & & & \\
\hline 27 & I teach students by asking them to memorize the language & & $\checkmark$ & & & \\
\hline 28 & I always use drills in teaching English & & & & $\checkmark$ & \\
\hline 29 & I make sure in teaching all language skills and components & & $\checkmark$ & & & \\
\hline 30 & School facilities don't allow us to properly teach the sunrise book & & $\checkmark$ & & & \\
\hline 31 & $\begin{array}{l}\text { Students' poor English language is an obstacle in the way of properly } \\
\text { teaching sunrise book }\end{array}$ & & & $\checkmark$ & & \\
\hline
\end{tabular}




\begin{tabular}{lll}
\hline 32 & 45 minutes are not enough to properly teach sunrise book & $\checkmark$ \\
\hline 33 & I need to attend an ELT method course & $\checkmark$ \\
\hline 34 & I need to be taught how to teach sunrise book & $\checkmark$ \\
\hline
\end{tabular}

Which of the following methods do you think should be used in teaching sunrise book? Please don't tick $\checkmark$ more than three methods

\begin{tabular}{lll}
\hline Method & Your choice \\
\hline 1. & Task-based language teaching & \\
\hline 2. & Presentation, Practice, Production (PPP) & \\
\hline 3. & Grammar-Translation Method & $\checkmark$ \\
\hline 4. & Direct Method & \\
\hline 5. & Communicative language teaching & \\
\hline 6. & Audio-lingual Method & \\
\hline 7. & Suggestopedia & \\
\hline 8. & The Silent way & \\
\hline 9. & Total physical response & \\
\hline 10. & Content based instruction & \\
\hline 11. & Community language learning & \\
\hline
\end{tabular}

Thank you very much for your time

The researcher:

Mr. Ivan H. Murad

\section{2: Interview Schedule}

\section{INVESTIGATING ENGLISH TEACHERS' AWARENESS OF THE TEACHING METHODS THAT SHOULD BE USED IN TEACHING THE SUNRISE SERIES IN ZAKHO CITY, DUHOK-IRAQ}

The following are questions for the interviews that will be conducted with some selected primary, secondary, and high school English teachers in order to answer the research questions that are as follows:

a. What do primary, secondary and high school English teachers in Zakho city know about the English teaching methods?

b. What methods do they use in teaching the English "Sunrise" Series?

c. Which methods should be used in teaching the English "Sunrise" Series?

d. What prevents them from utilising the already specified teaching methods in teaching the English "Sunrise" Series?

e. Do they need improvement in "the English teaching methods" and in "teaching the "Sunrise Series"?

Interview questions:

1. Which level of students do you teach? Primary, secondary, or high school level?

2. Have you studied English teaching methodologies? If yes, which methods of teaching have you studied?

3. In teaching English sunrise book, what methods do you use?

4. Do you always ask students to speak in the class?

5. Are you aware of the following methods and approaches of teaching?

$$
\text { Yes No }
$$

Presentation, Practice, Production?

Communicative Language Teaching

Task-Based Language Teaching

Community language learning

Audio-lingual method

Grammar translation Method

Direct Method

Content Based Instruction

6. Do you always translate grammar points from English into Kurdish? Why?

7. Who speaks more in the class? You? Or the students? Why?

8. Do you give chances to all students to speak in your class?

9. Which of the above methodologies should be used to teach English sunrise book? Why?

10. The method and approaches that should be used in teaching English sunrise book are: CLT and TBLT and some rare times PPP. These methods needs students to communicate and speak more than the teacher in the class, what prevents you from letting every student to speak in all your classes?

11. Do you need improvement in the following areas:

A. English teaching methodologies.

B. How to teach "Sunrise Book".

The researcher 


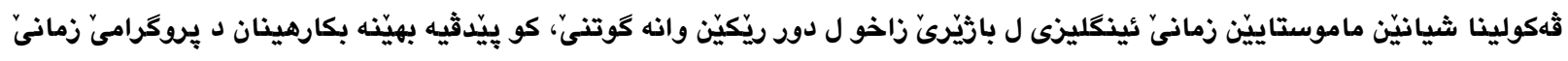
ئينكليزى (Sunrise)

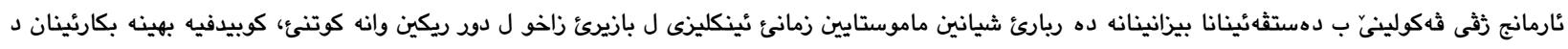

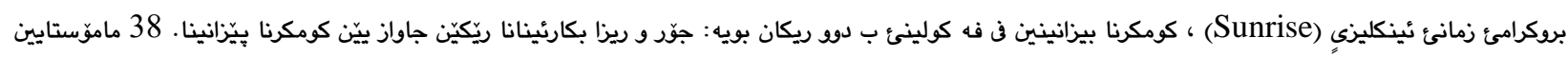

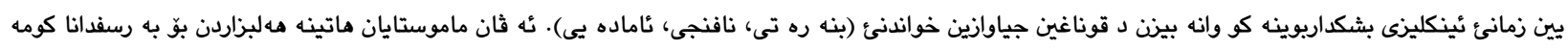

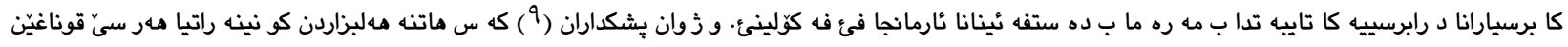

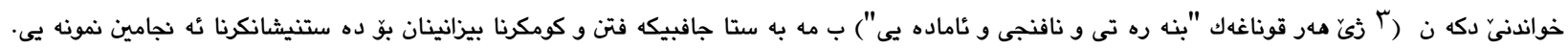

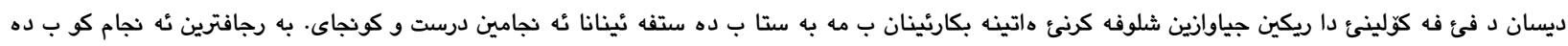

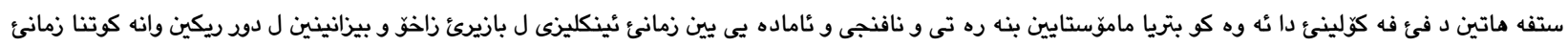

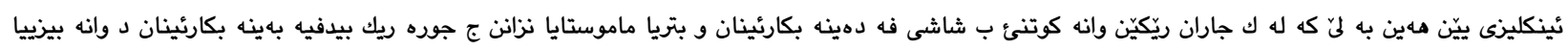

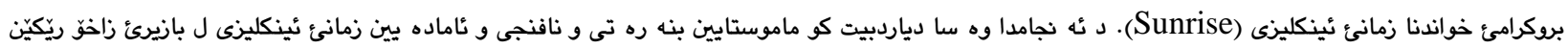

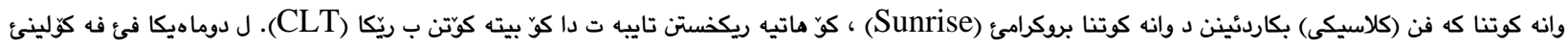

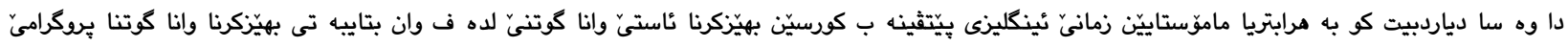

.(Sunrise)

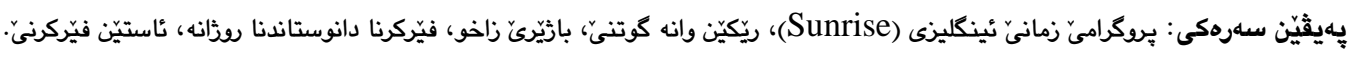

التحقيق في مدى معرفة اساتذة اللغة الانكليزية في مدينة زاخو حول طرائق التدريس التي يجب ان تستخدم في تدريس منهج اللغة الانكليزية (Sunrise)

الملخص: تهدف مذه الدراسة الى التحقيق في مدى معرفة اساتذة اللغة الانكليزية في مدينة زاخو حول طرائق التدريس التي يجب ان تستخدم في تدريس منهج اللغة الانكليزية

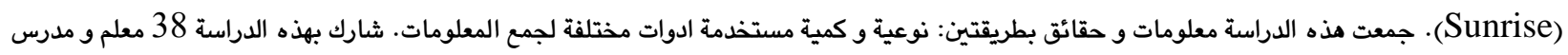
لغة انكليزية من مدينة زاخو والذين يدرسون في مختلف المراحل الدراسية (ابتدائية، متوسطة، و اعدادية). اختيرت هذه العينة لتجيب عن مجموعة اسئلة في استبيان صمم خصيصا لغرض تحقيق أهداف مذه الدراسة. من بين هولاء المشاركين في هذه الدراسة، تم اختيار 9 معلم و مدرس ليتم مقابلتة لجمع المعلومات.

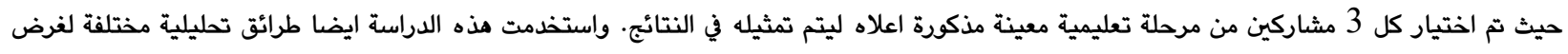

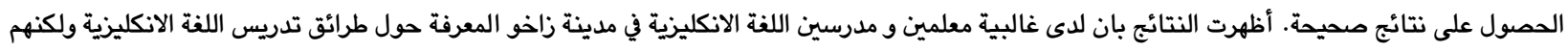
يجهلون الطرق التي يجب ان تستخدم في تدريس منهج ال (Sunrise) . أظهرت النتائج ايضا بان معلمين و مدرسين اللغة الانكليزية في زاخو يستخدمون طرائق

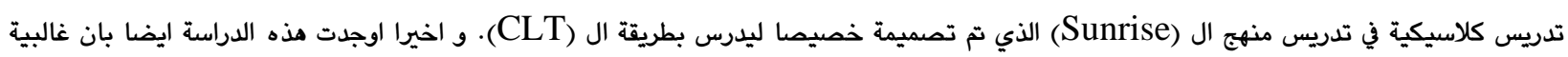
معلمين و مدرسين اللغة الانكليزية بحاجة الى التطوير في مجال التدريس و خصيصا في تدريس منهج ال (Sunrise). الكلمات الدالة: منهج ال (Sunrise)، طرائق التدريس، مدينة زاخو، مستويات التعليم، تعليم الحوار اليومي. 